This is the accepted version of a chapter published in 'Political Marketing and the 2015 UK General Election’ ed. Darren G. Lilleker and Mark Pack (2016)

\title{
Political Party Advertising and Marketing Strategies in the 2015 UK Election. ${ }^{1}$ Janine Dermody (Oxford Brookes)
}

\section{Overview}

This chapter evaluates the ad message strategies and creative executions of two major UK parties - The Conservatives and Labour. To what extent did the advertising connect with the overarching election marketing strategies employed by the parties? To what degree did the advertising engage the electorate to address their hopes and fears, thereby building their trust? To answer these questions, this examination utilises critical analysis of multisource evidence including research studies, documentary evidence, expert conference speakers, discussions and follow-up questions and commentary on social media. The chapter identifies good and bad practice and the strategic role advertising plays in the marketing of elections.

\section{Core Contextual Influences on the Campaign Messages}

Each election has its unique circumstances that influence the design and execution of each party's campaign strategy. The introduction to this book presents this electoral landscape. However, there are two issues noteworthy of consideration here because they significantly influenced the advertising campaigns. These are technology integration and the mood of the nation.

\footnotetext{
${ }^{1}$ To cite: Dermody, J. (2016). Political Party Advertising and Marketing Strategies in the 2015 UK Election. In D. Lilliker \& M. Pack (Eds.), Political Marketing and the 2015 UK General Election. Palgrave Macmillan.
} 
For the first time strategically integrated digitally advanced messages were proffered by the major political parties across media channels, particularly from the Conservatives. However this digital innovation was compromised by the narrow targeting of messages to marginal seats that rendered the parties election ad messages invisible for a significant proportion of the electorate (Dermody 2015).

The nations' mood was extensively influenced by the size of the country's debt, the fragility of Britain's economic recovery and job opportunities and austerity measures resulting in major cuts to public services. Tension and fear were evident among the less economically advantaged, with a greater gap between rich and poor during the lifetime of the previous parliament. Immigration, whilst being highly politically sensitive, did not dominate public consciousness so strongly. Where an anti-immigration sentiment did exist, this correlated with perceived limited job opportunities and inadequate and/or unequal access to public services. The economy therefore had to be central to the major parties election communication.

Within this landscape, the parties needed to gauge how best to strategically present their messages - using positivity to build hope or negativity to engender fear. Before presenting the campaigns, a synopsis of research on positive and negative attack advertising is given to inform analysis of the parties advertising messages.

\section{A Critical Synopsis of the Persuasiveness of Negative Attack versus Positive Election}

\section{Advertising Messages}

\section{The Persuasiveness of Negative Attack Ad Messages}

There is an evidence rich case for the persuasive power of negative attack political ads (Dermody and Hanmer-Lloyd 2011; Franz and Ridout 2007, 2010; Ruiter, Kessels, Peters \& Kok 2014). This originates from research signalling disliking a party influences voting 
decision-making attitudes and voter behaviour more strongly than liking (Dermody \& Scullion 2001), particularly for individual impression formation and evaluative decisionmaking. Thus negative messages, particularly personality attack ads, influence the electorate to judge attacked candidates to be less well-qualified, successful, honest, serious, sincere and more financially irresponsible. Accordingly attack ads are deemed to be more persuasive than positive ad messages, and win elections.

Using attack rhetoric illuminates and strengthens the 'cognitive footprint' of these ad messages because it increases their visibility and accessibility to become more memorable and comprehensible. Consequently the informative and motivating characteristics of attack messages engage the electorate, expanding voter turnout (Brader, 2005; Carraro, et al., 2010; Finkel \& Geer, 1998; Geer \& Geer, 2003; Martin, 2004). However these cognitively engaging effects are statistically weak and require circumspection. Additionally attack ads are powerful in arousing emotions (Brader 2006; Westen 2007), thereby motivating voting intention, particularly when emotions are positive. For example, partisans' happiness that the negative ad has highlighted 'lies' from opposing leaders or parties; and non-partisans satisfaction that the negative ads have identified weaknesses with a party's policies or character of a leader. For non-partisans, attack ads can justify and facilitate their choice of alternative party or leader, thereby easing their voting decision-making (Dermody, HanmerLloyd, Koenig-Lewis \& Zhao 2014). Attack ads must be 'evidence-based' however, or risk a backlash effect entailing voting for the opposition because of anger towards the sponsor's unsubstantiated and personal attacks on leaders or candidates.

In contrast, alternative studies on attack advertising indicate it increases political negativity, voter alienation and the ignominy of political argument, triggering a democratic deficit - a significant decline in participation and democratic accountability (Ansolabehere, et al., 1999; Cappella \& Jamieson, 1997; Kahn \& Kenney, 1999; Kaid, et al., 2000; Schenck- 
Hamlin, et al., 2000; Stevens, 2009).This is because attack advertising contributes to increasing political cynicism, declining political trust and reduced personal political efficacy and a lack of hope for the future (Dermody, Hanmer-Lloyd \& Scullion 2011; Dermody, Hanmer-Lloyd, Koenig-Lewis \& Zhao 2014; Schenck-Hamlin, Procter \& Rumsey 2000). These effects are further exacerbated by the permanent campaign. Overall an avoidance mindset is created where candidates are perceived to be undeserving of office and the political system is rejected because it contains unworthy and untrustworthy leaders. While this evidence has been accused of being overly dramatic, the demobilising effects of attack ads and mobilising effects of positive election ads are confirmed.

\section{The Influence of Positive Election Ad Messages}

Research on the positive effects of political advertising advance understanding in two areas: candidate evaluation and political motivation (Brader 2006; Carraro, Gawronski \& Castelli 2010; Matthews \& Dietz-Uhler 1998; Westen 2007).

The findings on candidate evaluation focus on candidate likeability and competence. With respect to likeability of candidates, individuals have been found to feel closer to politicians utilising positive self-promotion messages not negative ones aiming to undermine opponents. Regarding competence, candidates who employ negative advertising campaigns and not positive ones are judged to have higher competence, but are less likeable. As a consequence these candidates are perceived to be more powerful and agenic, but unfriendly compared with candidates articulating positive messages. Interestingly studies show explicit dislike of politicians who extensively use negative messages; however such candidates would still receive voting support. This is not a contradiction; voters are implicitly evaluating candidates' aptitude to govern versus their positive human characteristics. Essentially 
political leaders must be politically competent, but it is not critical for them to be liked; a combination of the two, however, is compelling.

Studies on political motivation show individuals' political enthusiasm can be stimulated by the neuropsychological effect of exposure to positive ads portraying success. This can increase eagerness to vote and enhance interest in the election campaign. Furthermore, these ads not only motivate those already interested and involved in politics, but can also facilitate some degree of universal mobilisation. Accordingly researchers conclude positive ads are influential in stimulating political involvement because they connect with the electorates' and politicians' hopes and ambitions for the future of their country and the stewardship of leaders who are competent (and liked). Overall then, the strength of positive election advertising is its capacity to create a sense of optimism and trust and stimulate electoral participation.

\section{The Conservative 2015 Advertising Campaign}

The Conservatives proved themselves to be the masters of election marketing in 2015. Their campaign was described as one of the most 'disciplined, focused and ruthless campaign in the history of British politics' (Swinford 2015). The Conservatives built their election strategy on five critical issues: the threat to Britain and the economy with a SNP Labour 'alliance'; the merits of the Conservative long term economic plan; utilising the positive persona of their leader David Cameron; ruthlessly attacking the Liberal Democrats; and relentlessly sticking to their strategic election marketing plan. Hence, for M\&C Saatchi, the Conservative's ad agency, the strategic role of the advertising was to energise Conservative voters to vote Conservative and persuade floating voters that voting for any other party was an unacceptable risk. To this end, the targeted advertising audience was voters in marginal seats and the media (influencing a largely partisan press and the more independent 
broadcasters to set the terms of the debate) (Sinclair 2015). The agency used data from YouGov and Ipsos Mori between 2014-2015 to inform their advertising messages and base them on 'fact'. This factual evidence reported who the public trusted the most with the economy and who would be the most capable Prime Minister; on both questions David Cameron was the outright winner (Sinclair 2015). Combining this evidence with the five critical issues of the overarching communication strategy, the foundations of the advertising campaign were established.

Accordingly, the Conservative advertising focused on conveying the threat of Labour sneaking to power with the support of the Scottish National Party (SNP). Labour would then become a puppet government as the SNP extracted 'payback' in advancing the interests of Scotland (embedding the suggestion this would be at the expense of the needs of England). This message was constantly and ruthlessly repeated across all their campaigning platforms as they effectively established this media agenda in-line with their ad strategy and motivated Conservative partisans and swing voters that this risk was too great and thus actively voting Conservative was critical. M\&C Saatchi believe that posters are an effective platform upon which to launch negative attacks on the opposition (Sinclair 2015) and the SNP threat enabled them to generate a series of attack creative executions to trigger an argument and persuade their audience of this danger by manipulating their fears. Hence, in personality attacks on Labour leader Ed Miliband, a succession of Conservative poster and digital ads featured Miliband trapped in the pocket of the SNP - waiting to do their bidding and as a puppet dancing to the tune of Alex Salmond and Nicola Sturgeon. The argument that this message generated was widely considered to be a decisive factor in Ed Miliband's declining popularity and Labour losing the election.

The Conservative's record on the economy was fundamental to their communication strategy. On the advice of political advisor - Jim Messina - they daily asserted they were the 
party with the long-term plan for effective economic recovery; stating Labour did wreck the economy and would crash it again. Thus their digital ads proclaimed: 'A recovering economy: don't let Labour wreck it', with Labour personified by demolition machines. These policyattack ads featured no voiceover, simply the message and the crash of the demolition ball. The credibility of the Conservatives message was underpinned by stronger economic growth compared with other G7 nations. In an earlier related economy ad that focused on the Conservatives, Cameron declared the country needed to stay on the road to stronger economic growth. 'Let's stay on the road to a stronger economy' featured the greatness of Britain (symbolised by the Union Jack flag) on a gently undulating road back to prosperity (symbolised by a lush green landscape personifying England; albeit the road was in Germany). All the economy advertising rhetoric featured an upbeat David Cameron displaying his energy and belief in himself and his party to succeed in making Britain's economy strong again. Hence this advertising entailed a mix of message styles; negative messages that attacked Miliband and Labour and positive messages praising themselves for their ongoing economic successes and their fortitude in seeing a difficult job done. As discussed within the Labour campaign below, both the economy and the SNP were major failures of Labour's election marketing campaign.

Unlike Labour, who were essentially unable to use their leader to front their communication in this election and the two previous general elections (2005, 2010), the Conservatives had a very valuable asset in David Cameron. They realised he was far more popular with the electorate than the party itself, hence he featured across the entirety of their election marketing campaign. Compounding this strength, the message he continually gave was that he, as the leader of the Conservatives, could be trusted with economic recovery and easing the burden on families (thus also stealing ground from Labour). Hence, even within an inherently attacking message, David Cameron provided the positive element of the message 
that said 'you can trust ME'. This combination of positivity and negativity throughout the advertising and wider communication messages was a highly potent strategy. Furthermore, because they used digital technology so effectively, for example the symbiotic interaction of their ad messages in election campaign films, across social media, interactive websites, etc, the power of the Conservatives messages was enhanced considerably. The flexibility provided by digital technology also meant that the Cameron asset remained strong. For example when opinion polls showed he was less 'emotional' compared with Ed Miliband, his message style was rapidly revised to portray his political passion, which increased positive public opinion. This is supported by neurological research from Neuro-Insight on the first Conservative and Labour PEBs (Andrew 2015). The Conservatives' first PEB of the election - 'securing a better future for you, your future and Britain' - featured positive messages on Conservative policy to decrease the deficit and invest in jobs, the NHS, education, the state pension and homebuilding. Including David Cameron near the end of the broadcast to confirm the centrality of these policies to HIMSELF and HIS Conservative party's aspirations enabled the electorate to see David Cameron the principled man and natural leader, not just the politician. Viewers subconscious responses in the Neuro-Insight study signalled that the Cameron content of the PEB was an emotional highpoint and highly memorable, as well as affirming his leadership qualities; whilst party-policy messages in the broadcast held less conviction for viewers (Andrew 2015). With such a powerful advantage, it is not surprising that this production format continued into their second and third PEBs, with Cameron presenting HIS positive messages about security under HIS Conservatives. However in the third PEB, a more negative message nuance was introduced to alert audiences to the risk to economic security if Labour was elected. While the fourth and final PEB, broadcast 2-days before the election day, still features a sincere and confident David Cameron, his message has now become much more negative in highlighting the severe risk to 
the economy and thus jobs, the NHS and security if any other party is elected. It is only now other parties are considered alongside Labour. However the main focus remains the threat of a SNP-backed Ed Miliband and Labour wrecking the economy, which is personified by the smashing of the economic clock of debt elimination and recovery. Thus this PEB also connected with their digital ads: 'a recovering economy-don't let Labour wreck it'; 'staying on the road to a stronger economy'; and Ed Miliband as a puppet of the SNP. The final seconds of this PEB show a wistfully smiling Cameron quietly reasoning with audiences to vote Conservative at the election to enable HIM to secure THEIR future.

No other party used digital marketing as strategically or successfully as the Conservatives did (Elder and Edmonds 2015). Alongside this it also appeared Conservative strategists and activists used a 'branded content' approach to de-market Labour leader Ed Miliband to the electorate, with unflattering and embarrassing 'incidents' posted across all Tory partisan channels. Their extensive marketing budget meant they could use multiple channels, and particularly digital platforms, to strategically pitch their messages and respond immediately to election issues as they unfolded. This gave them a strategic advantage in conveying their leader and policies, because of the simplicity of messages facilitated by advertising, in contrast to the 'clutter' of TV interviews, debates and newspaper coverage that can detract from message processing and adoption.

Overall, under the direction of their chief strategist, Lynton Crosby, the Conservatives stuck to their election campaign strategy, using minor adjustments to enhance their impact and used the full extent of media communication power to discredit Labour and Ed Miliband, who they saw as their strongest opponent. They largely ignored UKIP and saw the LibDems as a minor player - successfully 'stealing' seats from them via their wider marketing campaign. Interestingly then, as the election drew close and commentators and opposing party leaders spoke of panic within the Conservative election strategy team, insiders 
maintained there was no panic, the Conservative team remained very confident they were going to win the election (Sinclair 2015).

\section{The Labour 2015Advertising Campaign}

Labour's election strategy rotated around five primary issues: the deficit, reducing immigration, safeguarding the future of the NHS, increasing living standards and improving the future for young people. Within this, Labour positioned itself as representing the needs and aspirations of hard working British families hit by the austerity measures implemented by the coalition government. Thus their messages focused on boosting the economy, reducing economic cuts and protecting public services, e.g. the NHS. This message emphasis was evident in both their poster and PEB advertising as well as in other elements of their marketing campaign. In January 2015 Douglas Alexander stated the ad posters would focus on 'positive messages of hope', rather than the typically negative messages epitomized in most posters. However, their first official election ad poster - 'Next time they'll cut to the bone' - created by their agency Beattie, McGuiness and Bungay, (famous for their controversial campaigns), was a policy attack ad against the Conservatives. Designed to personify that Conservative cuts to public services would be extremely severe, the bones imagery symbolised the NHS was at utmost risk from Conservative 'bone deep' spending cuts. Similar ads were designed to convey the threat to public services and the NHS under a Conservative-led government, for example their ad 'The doctor can't see you now', which was a parody of the 1979 Conservative ad 'Labour isn't working'. Additionally, Labour's digital ad 'Are you watching closely' was a personal attack on David Cameron. This ad accused Cameron of his intention to hide behind the other leaders in the debate because 'his 
government's record is not very good'. Set against the background of Westminster, the bullet-style presentation of this message in the ad using bold-style red text, rather than vocalisation, and a fast-paced music and drum beat, gave their message the interactivity badly missing in their poster advertising. The ad ends with Labour's unifying proposition of ' $a$ better plan' embedded in their advertising: 'Labour has a better plan. We don't need to hide it.' While this ad enabled this message to be presented in a brutally simple way, as commentators and digital strategists observed, Labour's strategy in ensuring their digital messages reached key audiences was limited (Elder and Edmonds 2015; posted YouTube comments on the ad 2015). This is likely to be partially the result of their very limited marketing budget (compared with the Conservatives), and thus the courting of TV and press media to deliver their negative election messages. However Labour also appeared to misunderstand the targeting opportunities that social media offers, and thus they underplayed their strategic use of it in focusing their election ad messages (Elder and Edmonds 2015).

A Conservative policy-attack approach was also taken in four out of Labour's five PEBs, with the overarching message 'this is a choice between the Conservatives failing plan and Labour's better plan. A better future.' With three of them featuring celebrities and one historical-current day reminiscences, these PEBs focused on Labour protecting the NHS, raising living standards and giving a better future for youth. No mention was made of Ed Miliband; these were party not leader-centric. The Neuro-Insight research on the first Labour PEB, featuring Martin Freeman, revealed the absence of Ed Miliband was a problem because in viewers' minds it undermined Labour's credentials for leadership, whilst strengthening this for the Conservatives. Inevitably this was compounded in their 3 PEBs that adopted this message style approach. However the face-to-camera style of Freeman talking about the values and morality of Labour resonated as more personally relevant than the familyorientated message in the Conservative PEB (discussed above) (Andrew 2015). Utilised in 
two further celebrity PEBs featuring Labour advocates, perhaps this went some way to mitigate the leadership credibility issue created by Miliband's absence. This is, however, unlikely, because advancing strong leadership is fundamental to any election victory.

As the Conservatives ad posters depicting the threat of Labour leader Ed Miliband as a puppet of the Scottish National Party (SNP) were released and intensified by the media, it became evident that Ed Miliband needed to effectively establish his leadership qualities to govern and the party needed to robustly deny it would be a puppet of the SNP (which it did far too late in the last week of the campaign). While Ed Miliband was doing well in the opinion polls when the election was called, there were no posters featuring him or his credentials to lead the next British government. Within the advertising, this responsibility was left to one out of Labour's five PEBs, leaving other platforms to present their leader, for example the leader debates. The fourth PEB - 'Ed Miliband: A Portrait' - was aired on April $28^{\text {th }} 2015$, eight days before the date of the election, at a point when the tide of public opinion was beginning to swing back to Conservative leader David Cameron. This broadcast strongly featured discussions about Miliband's values and why he was ready to offer himself as Prime Minister to enable better lives for hardworking people struggling to live and proposer in Britain. In common with the other Labour PEBs, he emphasised the need to protect public services, and principally to rescue the NHS from Conservative cuts. Overall Miliband presented himself in a somewhat evangelical style as the saviour of Britain who would fight to restore hope to struggling hard working families and young adults and safeguard the future efficacy of the NHS. While the allocation of one PEB and no posters was undoubtedly partially a strategic decision, similar to 2005 and 2010, Labour strategists presented very little of the qualities of their leader to the electorate through the lucidity that the lens of advertising accords. Furthermore they did not respond to the SNP taunts through their advertising, and neither did they generate responsive digital ads or use the wider media to effectively respond. 
This created an opportunity for Conservative strategists, who appeared to trap Miliband in the glare of their relentless messages portraying his weaknesses and secret willingness to sell Westminster to Scotland in order to win the election. Alongside this fear, Miliband also had to battle against increasing public fears that Labour was against reducing the deficit (again fuelled by the Conservatives and media). Notably, while this reduction might have been implied in their PEBs, Labour never directly mentioned it in their advertising rhetoric, an omission that did not bode well in the latter days of the election contest. Accordingly, as the election date drew closer and his popularity began to recede, his election messages now appeared to lack conviction. However, the Labour election campaign team were still very confident they would achieve enough votes to form the next British government, and this overconfidence was probably detrimental to the receptivity of their messages in the latter phase of the election contest.

\section{Analysis of the Conservative and Labour 2015 Advertising Campaigns}

What major issues then arose in the Conservative and Labour advertising campaigns?

\section{Conservative Advertising Campaign}

The Conservatives election victory was attributable, in part, to their marketing strategy and their discipline in staying 'on message' in their advertising. Using research evidence, they understood the electorate's mindset well. Their policy and leader-attack ad messages on the economy and the threat of Miliband selling-out to the SNP resonated with Conservative partisans and active voting segments, namely older, more affluent, employed and those residing in business-rich constituencies. This was in stark contrast to Labour voter demographics. Furthermore, importantly they gained the votes of the undecided, which their opponents had hoped to win. 
Consequently, for those who voted Conservative, the attack messages aided their emotional and cognitive impression formation and evaluative decision-making in affirming the credibility and their liking of David Cameron and his Conservatives and confirming their dislike of Labour and Miliband. Furthermore the persuasiveness of the advertising was compounded considerably by Conservative positive ad messages entailing the positive selfpromotion of David Cameron to draw voters closer to him and his party and motivate them to vote for HIM. Therefore inherent within their advertising messages, voters were invited to join WITH Cameron to become part of HIS team to secure the future of OUR Britain. This is in stark contrast to being governed under a political party and reflects the integration of value co-creation and customer experiences inherent within much contemporary commercial marketing. Accordingly the objectives of the advertising campaign were met.

Overall the use of positive and negative message strategies was skilfully played; using negative attack messages to reinforce the competencies of David Cameron to govern, and positive messages to create liking of him and motivate turnout; thereby stimulating trust. This was magnified by the extensive strategic use of digital technology. Overall the charisma of David Cameron, and thus his capacity to connect with voters' intelligence and emotions, was the most valuable strategic asset the Conservatives possessed - and this potency was distilled throughout the advertising and wider marketing strategy in advancing trustworthiness and proficiency. Hence while some of their advertising was criticised for being too overcrowded to process, e.g. the PEBs and the road to recovery poster, and too narrowly targeted, this was mitigated by the overarching Cameron persuasive effect in winning over voters to Cameron's Conservative party. Therefore, from a strategic marketing perspective, the Conservative campaign was far more advanced than Labours.

\section{Labour Advertising Campaign}


Critics accused the Labour campaign of being out of touch with the fears, aspirations and reality of normal working people. It failed to address their concerns on immigration, welfare and job creation and instead presented itself as the party for the "needy and greedy" (cited in Wintour 2015). Labour was perceived to be demonising the private sector and favouring those deliberately choosing not to work, at the expense of 'hardworking families'. Compounding this, critics maintained the campaign messages failed to address austerity and the deficit and immigration was taboo (Keeble and Straw 2015). Furthermore, Labour's values were undermined by personifying voters as calculative consumers not citizens - the selfish-voter (Dermody \& Hanmer-Lloyd 2004). Yet these issues lay at the heart of Labour's campaign, so how valid are these criticisms?

The advertising campaign focused on the threat to public services, a 'hiding' David Cameron and the values of Labour and their leader Ed Miliband. This was wrapped within a negative policy-attack message style, with elements of personality attack on Cameron, alongside some positive voicing on values. The deficit and austerity were not made explicit in any ad messages (albeit they were embedded in some campaign rhetoric), and neither was immigration. This suggests key messages advanced by Labour did not connect with the publics' hopes and fears. This was a lost opportunity to use advertising to inform and build confidence to grow public trust in Labour. Particularly so because the simplicity in Labour's stripped-back PEB ads had greater capacity to effectively gain attention and avoid misunderstanding than the more crowded Conservative ad messages. Their persuasiveness might also have increased had these messages contained more positive content to facilitate better candidate evaluation and liking of Miliband. Labour's messages did get through to some voter segments however - younger, unemployed, low-earners and ethnic minorities (Rudgard 2015), negating some of the criticism of the campaign. Problematically, though, 
turnout amongst them is historically lower than their affluent older peers and Labour failed to attract the 'undecided' who determined the election outcome.

Miliband's absence from most of Labour's advertising (except one PEB) was damaging, particularly contrasted with a charismatic Cameron who dominated the Conservative campaign. For example he could have featured in digital ads rising above the Tory SNP jibes and asserting positive messages about a 'Labour future', using social media more strategically in targeting dissemination of core messages like this.

Consequently there were three primary weaknesses in the Labour advertising and wider marketing campaign. Firstly, failing to communicate convincing and trustworthy messages reflexive of the policies and values of the Labour party that would alleviate the 'risk-taking fears' of pro-Labour and non-Conservative voting segments who turnout. Secondly, failing to portray Ed Miliband's leadership competence and trustworthiness to convince voters and media of his Prime Ministerial qualities. Thirdly, failing to revise their marketing strategy in light of the Conservative marketing machine. They were never going to gain voters by arguing directly with David Cameron. Instead they should have been focusing on constructing policy attack and positive messages to win votes from the LibDems and UKIP, with messages emphasising belonging with Miliband's Labour, not being 'under' its governance. This missed opportunity to provide a viable alternative choice facilitated a big swing of LibDem/UKIP voters to the Conservatives; they had nowhere else to go. This signalled an arrogance within Labour's strategic campaign team and hence a profound failure to understand the nation they wanted to govern. It is therefore not surprising they lost the election, but more fundamentally why they imploded.

\section{Conclusion}


Ultimately this election was not a choice between parties. It was a contest between the credibility of leaders in almost presidential style - an emotive-cognitive appraisal of the battle between David Cameron and Ed Miliband. It showcased how positive election messages, combined with personalised positive rhetoric and evidence-based policy-attacks, can be highly persuasive in engaging and motivating the electorate to vote and in decreasing a cynical mindset. Thus it sets further precedent for positive advertising message strategies in future election campaigns, thereby addressing some ethical concerns surrounding attack advertising. David Cameron's ownership of the Conservative party showed genius, (as did Tony Blair's ownership of New Labour). It gave strength and intelligence to the campaign advertising and marketing by illuminating the party as an extension of the leaders selfidentity, and thus their values and ambitions, and it was this Cameron identity that voters wanted to belong to - to be part of Cameron's in-group.

This appraisal reaffirms the importance of advertising in election marketing, and digital technology enhances its persuasive power. Accordingly while election advertising is likely to metamorphose before the next election, it remains an integral part of strategic election marketing, most notably because of its capacity to meaningfully connect voters with political leaders across multiple platforms and give them a sense of belonging and empowerment.

So what kind of election advertising will emerge from this metamorphosis? Specifics of this evolving species remain fuzzy; however its evolution will be driven by digital technology and science.

Digital technology and social media will facilitate an exponential increase in the positive and negative 'political stories' told about human interactions with MPs, parties and their policies. Consequently, advertising could hybridise into a mixture of marketing messages, entertainment and education. This future is already here via branded content. 
Building on this, advances in neuroscience increase comprehension of the neurological impact of political messages on the human brain, and thus how to 'switch it on and off' and to activate it at a higher level. Currently much neuromarketing focuses on the basic human reptilian brain (amygdala), which entails instant gratification of consumers' primeval human instincts, for example attack ads declaring 'don't vote for them, you will pay more tax'. However, neuroscience offers more than this; it enables greater understanding of how the 'superior human brain (the cortex) functions to enable our empathic-thinkingmindful selves. Hence, this new election advertising will have evolved to interact with this deeper human self, thereby helping to advance democratic engagement. This is in-line with experiential, relational and co-creation developments within marketing and it may well negate the use of personalised attack ad messages and much greater use of positive messages.

In the future it will be voters and their stakeholders who will be the change agents the storytellers - not politicians and their strategy and media agents. These tales will embrace advertisings narrative roots to stimulate cognitive and emotional connectivity among electoral stakeholders. Thus, the technological-scientific metamorphosis of advertising will enable it to do what it does best - give humans the stories that enable them to make connections with what is good for themselves, society and democracy. 


\section{References}

Andrew, H. (2015). Tory v Labour party political broadcasts: who won? The Guardian, May $1^{\text {st }}$. http://www.theguardian.com/media-network/2015/may/01/tory-labour-party-politicalbroadcasts-who-won

Ansolabehere, S., Iyengar, S., \& Simon, A. (1999). Replicating Experiments Using Aggregate and Survey Data: The Case of Negative Advertising and Turnout. American Political Science Review, 93(4), 901-909.DOI: 10.1177/0093650208315976

Brader, T. (2005). Striking a Responsive Chord: How Political Ads Motivate and Persuade Voters by Appealing to Emotions. American Journal of Political Science, 49(2), 388-405. DOI:10.1111/j.0092-5853.2005.00130.x

Cappella, J., N., \& Jamieson, K., Hall. (1997). Spiral of Cynicism: The Press and the Public Good. Oxford: Oxford University Press.

Carraro, L., Gawronski, B., \& Castelli, L. (2010). Losing on all fronts: the effects of negative versus positive person-based campaigns on implicit and explicit evaluations of political candidates. British Journal of Social Psychology, 49(3), 453-470.

DOI:10.1348/014466609X468042

Dermody, J. (2015). Marketing the 2015 British General Election: The Invisible Campaign? Jackson, D. and Thorsen, E. (Eds.), UK Election Analysis 2015: Media, Voters and the Campaign. Early reflections from leading UK academics. http://www.electionanalysis.uk/

Dermody, J., and Hanmer-Lloyd, S. (2011). An Introspective, Retrospective, Futurespective Analysis of the 2010 British General Election Advertising Campaign. Journal of Marketing Management, 27 (7/8), 736-761. DOI:10.1080/0267257X.2011.587826

Dermody, J. and Hanmer-Lloyd, S. (2004). Segmenting Youth Voting Behaviour through Trusting-Distrusting Relationships: A Conceptual Approach, International Journal of Nonprofit and Voluntary Sector Marketing, 9(3), 202-217. DOI:10.1002/nvsm.248

Dermody, J., Hanmer-Lloyd, S., Koenig-Lewis, N., \& Zhao, A. L. (2014). Young British Partisans' and Non-Voters' Processing of Attack Election Advertising and the Implications for Marketing Politics. Journal of Marketing Management, 30 (9-10), 974-1005. DOI: 10.1080/0267257X.2014.933866

Dermody, J., \& Scullion, R. (2001). An exploration of the advertising ambitions and strategies of the 2001 British general election. Journal of Marketing Management, 17(9-10), 969-987. DOI:10.1362/026725701323366700

Elder, C. and Edmonds, T. (2015). 2015 really was the first digital general election: here are 7 lessons you should know. The Telegraph, July $23^{\text {rd }}$.

http://www.telegraph.co.uk/news/general-election-2015/11757682/2015-really-was-the-firstdigital-general-election-here-are-7-lessons-you-should-know.html

Finkel, S. E., \& Geer, J. G. (1998). A Spot Check: Casting Doubt on the Demobilizing Effect of Attack Advertising. American Journal of Political Science, 42(2), 573-595.

Franz, M., \& Ridout, T. N. (2007). Do political ads persuade? Political Behavior, 29(4), 465491. DOI:10.1007/s11109-007-9032-y

Franz, M., \& Ridout, T. N. (2010). Political Advertising and Persuasion in the 2004 and 2008 Presidential Elections. American Politics Research, 38(2), 303-329. DOI:

$10.1177 / 1532673 \times 09353507$ 
Geer, J. G., \& Geer, J. H. (2003). Remembering Attack Ads: An Experimental Investigation of Radio. Political behavior, 25(1), 69-95. DOI: 10.1023/A:1022904428357

Kahn, K. F., \& Kenney, P. J. (1999). Do negative campaigns mobilize or suppress turnout? Clarifying the relationship between negativity and participation. American Political Science Review, 93(4), 877-889.

Kaid, L. L. (2012). Political advertising as political marketing: a retro-forward perspective. Journal of Political Marketing, 11(1-2), 29-53. DOI: 10.1080/15377857.2012.642731.

Martin, P. S. (2004). Inside the Black Box of Negative Campaign Effects: Three Reasons Why Negative Campaigns Mobilize. Political Psychology, 25(4), 545-562. DOI: 10.1111/j.1467-9221.2004.00386.x

Matthews, D., \& Dietz-Uhler, B. (1998). The black-sheep effect: How positive and negative advertisements affect voters' perception of the sponsor of the advertisement. Journal of Applied Social Psychology, 28, 1903-1915.DOI: 10.1111/j.1559-1816.1998.tb01352.x

Rudgard, Olivia. (2015). How did the Conservatives win the general election? The Telegraph, $13^{\text {th }}$ May. http://www.telegraph.co.uk/news/politics/conservative/11599600/How-did-theConservatives-win-the-general-election.html

Ruiter, R.A.C., Kessels, L.T.E., Peters, G-J.Y. \& Kok, G. (2014). Sixty years of fear appeal research: Current state of the evidence. International Journal of Psychology, 49(2), 63-70, DOI: $10.1002 /$ ijop. 12042

Schenck-Hamlin, W. J., Procter, D. E., \& Rumsey, D. J. (2000). The influence of negative advertising frames on political cynicism and politician accountability. Human Communication Research, 26(1), 53-74. DOI: 10.1111/j.1468-2958.2000.tb00749.x

Sinclair, J. (M\&C Saatchi). (2015). Posters and Politics. Conference - Parties, Media, Voters: the 2015 Campaign. Elections, Public Opinion and Parties Specialist Group - Political Studies Association. 13-14 July, London, UK.

Stevens, D. (2009). Elements of Negativity: Volume and Proportion in Exposure to Negative Advertising. Political Behavior, 31(3), 429-454. DOI: 10.1007/s11109-008-9082-9

Swinford, S., (2015). Election 2015: How David Cameron's Conservatives won. The Telegraph, $8^{\text {th }}$ May. http://www.telegraph.co.uk/news/general-election2015/11592230/Election-2015-How-David-Camerons-Conservatives-won.html

The Guardian Editorial. (2015). The Guardian view on the Labour defeat: a failure of political direction - and of strategy. May $9^{\text {th }}$.

http://www.theguardian.com/commentisfree/2015/may/08/guardian-view-labour-defeatfailure-storytelling-strategy

Westen, D. (2007). The Political Brain. New York: Public Affairs.

Wintour, Patrick. (2015). Labour candidates attack 'predictable and out of touch' election campaign. The Guardian, July $28^{\text {th }}$. http://www.theguardian.com/politics/2015/jul/28/labourcandidates-attack-predictable-out-of-touch-election-campaign

Keeble, S. and Straw, W. (Eds.). (2015). Never Again. Lessons from Labours Key Seats. Fabian Society. ISBN 978-0-7163-4124-6. http://www.fabians.org.uk/ 


\section{Links to a selection of Conservative and Labour election advertising}

All 2015 party election broadcasts can be found online. They are currently accessible on BBCiplayer until summer 2016: www.bbc.co.uk/iplayer

\section{Conservative:}

The road to a stronger economy: http://www.theguardian.com/politics/2015/jan/02/tories-gofor-country-road-to-take-the-economic-message-home\#img-2

A recovering economy: www.youtube.com/watch?v=seYDn3L2UKc

Alex Salmond: ready to "call the tune":

https://www.youtube.com/watch?v=6JeYlBRvUeE\&feature=youtu.be

Ed Miliband as SNP puppet:

https://twitter.com/Conservatives/status/589703032427978752/photo/1

\section{Labour:}

Next time they'll cut to the bone:

http://labourlist.org/wp-content/uploads/2015/03/unnamed4-440x220.jpg

Are you watching closely: www.youtube.com/watch?v=Wgf_Sj5f_AE

The doctor can't see you now:: http://labourlist.org/wpcontent/uploads/2015/04/unnamed.png 